\title{
UNSPECIFIC EVOKED POTENTIAL OF WAKING RABBIT BRAIN
}

\author{
By \\ KiICHiRo TAGUCHI \\ From the Department of Otolaryngology, Faculty of medicine \\ Shinshu University, Matsumoto (Director: Prof. T. Suzuki)
}

The refractory periods of waking rabbit brain to auditory and electrical stimulation were examined by means of the superimposing technique and the summation method in the average response co. mputer. The refractory periods were determined by the appearance of the unspecific evoked responses to second stimuli. This experiment was designed on the table of the orthogonal arrays of three factors $\left(\mathrm{H}_{3 \cdot 97}\right)$.

Following results were obtained:

1) The individuality of rabbits and the strength of the first stimuli had no influence upon the refractory periods, while the second stimuli produced a significant powerful effect.

2) There were no mutual interaction between the three factors (the individuality of the rabbits, the strength of the first stimuli and that of the second stimuli).

3) The cross-modality interaction between the click and electric shock showed that the evoked response is essentially the same as the secondary discharge of animal in sleep or the V-potential in waking human brain.

\section{覚醒時家鬼における非特異性誘発電位”}

信州大学医学部耳舉咽唉科学教室（主任：鈴木䈍郎教授）

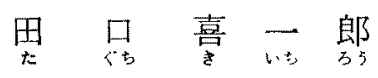

\section{腥言}

感覚刺激に対する大脑誘発電位は古来幾多の研究があ るがここれは 1）覚醒時反応と2）睡服時反応とに大別 される. 前者は更にa) primary response, b) association area response c) vertex-potential，後者は a) primary response, b) secondary discharge, c) Kcomplex 等に分けることができる.

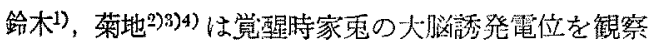

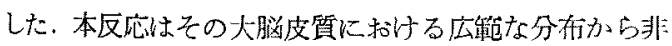
特異性の反応であ万らと子想され，人閒のV-potential に相当するものであるらと推测さ机たが，この点们时す る充分な㛟討はまだなされていない，

最近著者はこの点を解明するために，重权合わせ法に 上る刺激閒陽を目標とした央駼を施行し，佮せて加算法

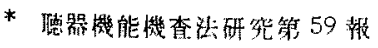

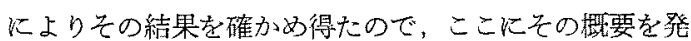
表する。

\section{実験方法}

\section{1) 奏踰動物}

多数の白色成熟家鬼中より，free field で 60dbSL の click（持続時間 $0.5 \mathrm{msec}$ ) を与えた時及び坐骨神経 飞 $4.0 \mathrm{~V}$ の電気刺激 $(0.5 \mathrm{msec})$ を加光大時，脳波上飞 謤発電位の見られるもの3頭を at random に選儿だ。

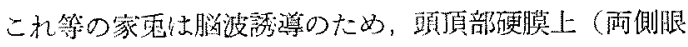
嚄後縁它絬ぶ線」で矢状面との交文点）飞活性電極を固 远してから1力月以上絓過したもので，項部に不関雨極 を刺入した，又電気刺激を薂入するため，左側坐骨神稀 に同心状針状電極刺入固定した。

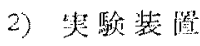

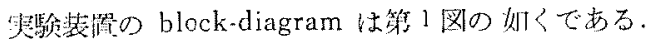

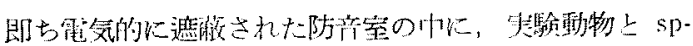

$10-41$ 
第1図 实験装置の block-diagram

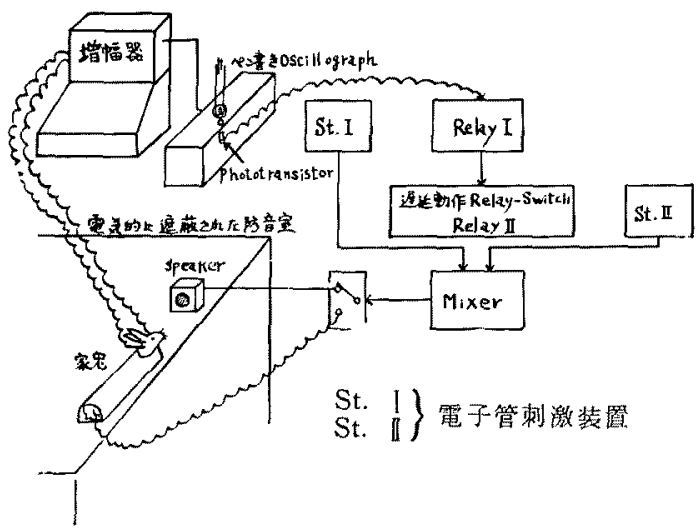

eaker のみを入れ，脳波記録装锩，audiometer 並びに 椧者は隣室位位置した。

a . 刺激装

刺激は前記 block-diagram の電子管刺激装置（日本 光電製 MSE 20) によつた。これより発生した刺激を 1 つは speaker を通し 持続 $0.5 \mathrm{msec}$ 程度の pulse 性

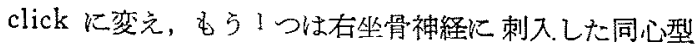
針状双極電極を通して電気的 shock を与えた。

b. 脳波記録湾置

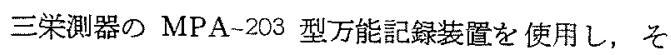
の一部は重ね合わせ法のできるよう改変した，增幅器は $50 \mu \mathrm{V}$ の入力に対し，ペン先が $15 \mathrm{~mm}$ の振幅を有する 上うに調節した。記録用紙の進行速度は毎秒 $2.5 \mathrm{~cm}$ で あつた。

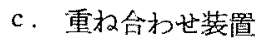

インク書き oscillograph の描写板の片端に小孔を穿 ち, その直下に phototransistor (sony $2 \mathrm{~T}-102$ ) を取 り代计，描写板小孔值上には光源として小型電球を設置 し，その光が小孔を経て transistor に投ぜられるよら にする、 phototransistor は真空管による遅延䡃作 rel一 ay-switch 装置を駆動し，その瞬間から任意の時間々隔 (0.1〜10秒) をもつて2つの pulse が別々の電子管刺 激装置を働か女，所定の click 又山電気 shock を発生 する。

記録用紙を約 $250 \mathrm{~cm}$ に切断し，電球の直下を通る位 置に約 $30 \mathrm{~cm}$ 間隔に $20 \mathrm{~mm} \times 10 \mathrm{~mm}$ の短形の孔をあ山 る。その用紙を oscillograph の迴転盤に取り付け，两 端を貼り命わせて環状とする。

今 oscillographを作動させると，用紙が環状のため， 描記される脳波々形は何回でも同じュースを通り，click 並びに電気 shock は何時も記録用紙の同し位置で与兄 られる.本実験では原則として10回重ね合わせて行つ た。

3) 揦激の与光方

a. click 刺激

$60,80,100 \mathrm{dbSL}, 0.5 \mathrm{msec}$ の click を直交配列表の 教觉るところにより，夫ネ2つずつ組合わせ，各組合わ せとついて $0.1,0.3,0.5,0.7,0.9,1.5,3.0,5.0$ 秒の 刺激間隔にて重权合わせ法に上り記録し，第 1 刺激，第 2 刺潡共に反応の見られる時間をるつて求める不応期と Lた.

b. 電気 shock

刺激用同心双極電極で，4，5.3，6.6V，0.5 msec $の 3$ 水 準の刺激を click 刺激と同様の 万法で与六て，不応期 を測定した。

c. click と電気 shock との交互作用

前記 $\mathrm{a}, \mathrm{b}$ の実験に上り十分に反於が見られ，且つ

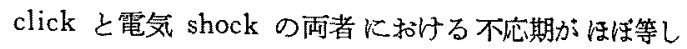
いと考兄られる click 刺激 $80 \mathrm{db}$, 電気 shock $5.3 \mathrm{~V}$ を用い，i）電気 shock に click を先行させた場合， ii）click に電気 shock を先行させた場合の 2 稉の実䮖 をる頭の家兔に施行し，同様に不応期を目標として， click と電気 shock との交互作用の有無を㭘討した。

4)な括 click に関しては重悋合わせ法と全く同し 実駼を三栄測器製作の Average Response Computer (ARC) K上り，30 回加算を行い，第 1 反応汶対する第 2 反応の（振幅の）回復に要する刺激間陽を求めた。

\section{実呀成樍}

3 因子 (動物，第 I 刺激，第 2 刺激)，3 水準 (3匹， 前記 click の3 段階の強さ，同じく電気 shock の3 段 階の強さ），実験回数 27 回の直交配列表（H s.27）(第 1 表）を用いて，各組合わせに関する笑踰を行い，第2 刺 激に対する反応分現われるに要する刺激間隔（不応期）

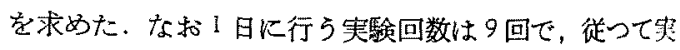
験に要した日数は重权合わせ法6日 (click, 電気 shock 各3日ずつ)，ARCによる click の実戨 3 日計9日で

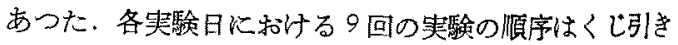
で決めた。

その実験成綨は第 2 表の如くである、本表より次のこ とが分る(第 2 図)。 
表 1 表 $\mathrm{H}_{3: 47}$ の装

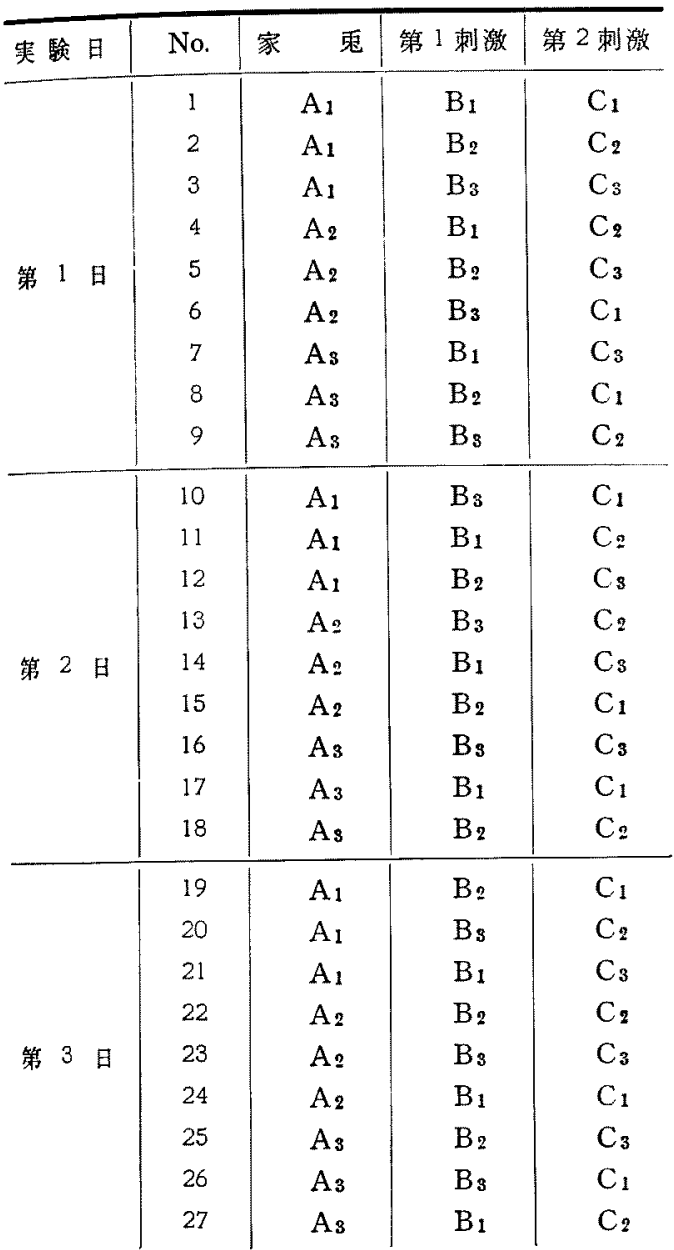

$A_{1}, A_{2}, A_{3}: 3 匹 の$ 家鬼

$\left.B_{1}\right)$ click $60 \mathrm{db}$,

$\mathrm{C}_{1}$ ) 電気 shock $4.0 \mathrm{~V}$

$\mathrm{B}_{2}$ ) click $80 \mathrm{db}$

$\left.\mathrm{C}_{2}\right\}$ 電铱 shock $5.3 \mathrm{~V}$

$\mathrm{B}_{3}{ }^{\prime}$ click $100 \mathrm{db}$

$\mathrm{C}_{8}$ 電哭 shock $6.6 \mathrm{~V}$

1) click-click 刺激の場合

この場合，重权合わせ法でも(第了表)，加算法でも (第 5 表) 共に次のことが云える。

a、動物の個体差はあるが，特性值に影響を及ぼさ tsh.

b. 第 1 click 刺激も特性值に影聯を及活さない。

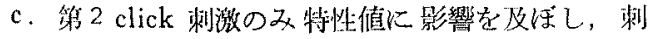
激の引さが大になると不応期は短くなる。
第 2 表 第 2 刺激に対与る反応出現に

必要な刺激間隔(秒)

\begin{tabular}{|c|c|c|c|c|}
\hline & \multicolumn{2}{|c|}{ 車朴合衫浽 } & \multirow{2}{*}{\multicolumn{2}{|c|}{$\frac{\text { 算 }}{\text { click }}$}} \\
\hline & \multirow[b]{2}{*}{ click } & \multirow[b]{2}{*}{ 電気 shock } & & \\
\hline & & & 出晲㭙間 & 回倠的間 \\
\hline 1 & 5,0 & 5.0 & 3.0 & $(5.0)$ \\
\hline 2 & 3.0 & 3.0 & 1.5 & $(3.0)$ \\
\hline 3 & 0.9 & 0.9 & 1.5 & $(5.0)$ \\
\hline 4 & 0.9 & 0.5 & 0.9 & $(1.5)$ \\
\hline 5 & 1.5 & 0.9 & 0.5 & $(1.5)$ \\
\hline 6 & 3.0 & 1.5 & 0.9 & $(3.0)$ \\
\hline 7 & 0.5 & 0.5 & 0.5 & $(0.9)$ \\
\hline 8 & 5.0 & 1.5 & 0.7 & $(1.5)$ \\
\hline 9 & 1.5 & 3.0 & 0.9 & $(3.0)$ \\
\hline 10 & 1.5 & 3.0 & 0.7 & $(30)$ \\
\hline 11 & 1.5 & 1.5 & 0.7 & $(1.5)$ \\
\hline 12 & 0.9 & 0,9 & 0.3 & $(0.5)$ \\
\hline 13 & 3.0 & 0.9 & 0.7 & $(0.7)$ \\
\hline 14 & 1.5 & 0.3 & 0.3 & $(0.5)$ \\
\hline 15 & 5.0 & 1.5 & 0.7 & $(3.0)$ \\
\hline 16 & 0.9 & 0.5 & 0.5 & $(0.7)$ \\
\hline 17 & 0.9 & 1.5 & 0.9 & $(0.9)$ \\
\hline 18 & 0.7 & 0.5 & 0.7 & $(1.5)$ \\
\hline 19 & 3.0 & 3.0 & 3.0 & $(5.0)$ \\
\hline 20 & 3.0 & 3.0 & 0.3 & $(0.3)$ \\
\hline 21 & 1.5 & 0.9 & 0.3 & $(1.5)$ \\
\hline 22 & 1.5 & 1.5 & 1.5 & $(3.0)$ \\
\hline 23 & 3.0 & 1.5 & 1.5 & $(3.0)$ \\
\hline 24 & 3.0 & 5.0 & 3.0 & $(3.0)$ \\
\hline 25 & 1.5 & 0.7 & 0.5 & $(0.5)$ \\
\hline 26 & 1.5 & 1.5 & 3.0 & $(5,0)$ \\
\hline 27 & 1.5 & 0.9 & 1.5 & $(1.5)$ \\
\hline
\end{tabular}

山現時間：第 2 刺激による区㧤の出現に要する 刺激間謜

回復時間：第 2 刺激に上石反纳がこれと同し栬 さの第1测激による反灾の大きさに 潼与るに要する刺激間隔 d. 因子間登互作朋はむると云えない

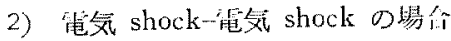

この場合，重权台わせ法の们つたみ゙, click-click の場合と企く同様なことが云える(第 4 表).

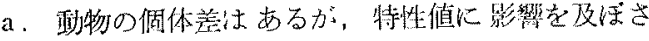
tsh.

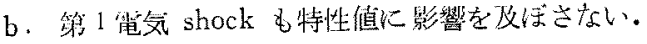


第2図観察例
1) 溜薌剩激
維合放岲第2日目
家身: $\mathrm{A}_{2}$
第 1 制濒: $60 \mathrm{db}$
筙 2 刺激: $100 \mathrm{db}$

刺激閒履

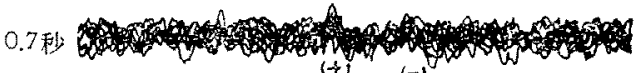
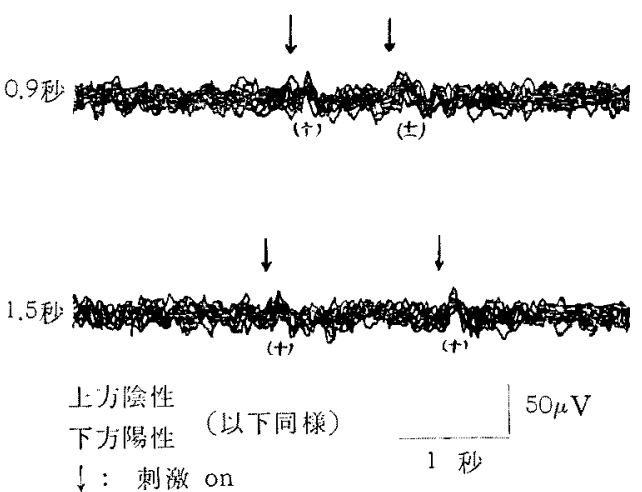

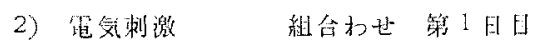
家乘: $\mathrm{A}_{3}$

第 1 刺激： $5.3 \mathrm{~V}$

第, 2 测暴: $4,0 \mathrm{~V}$
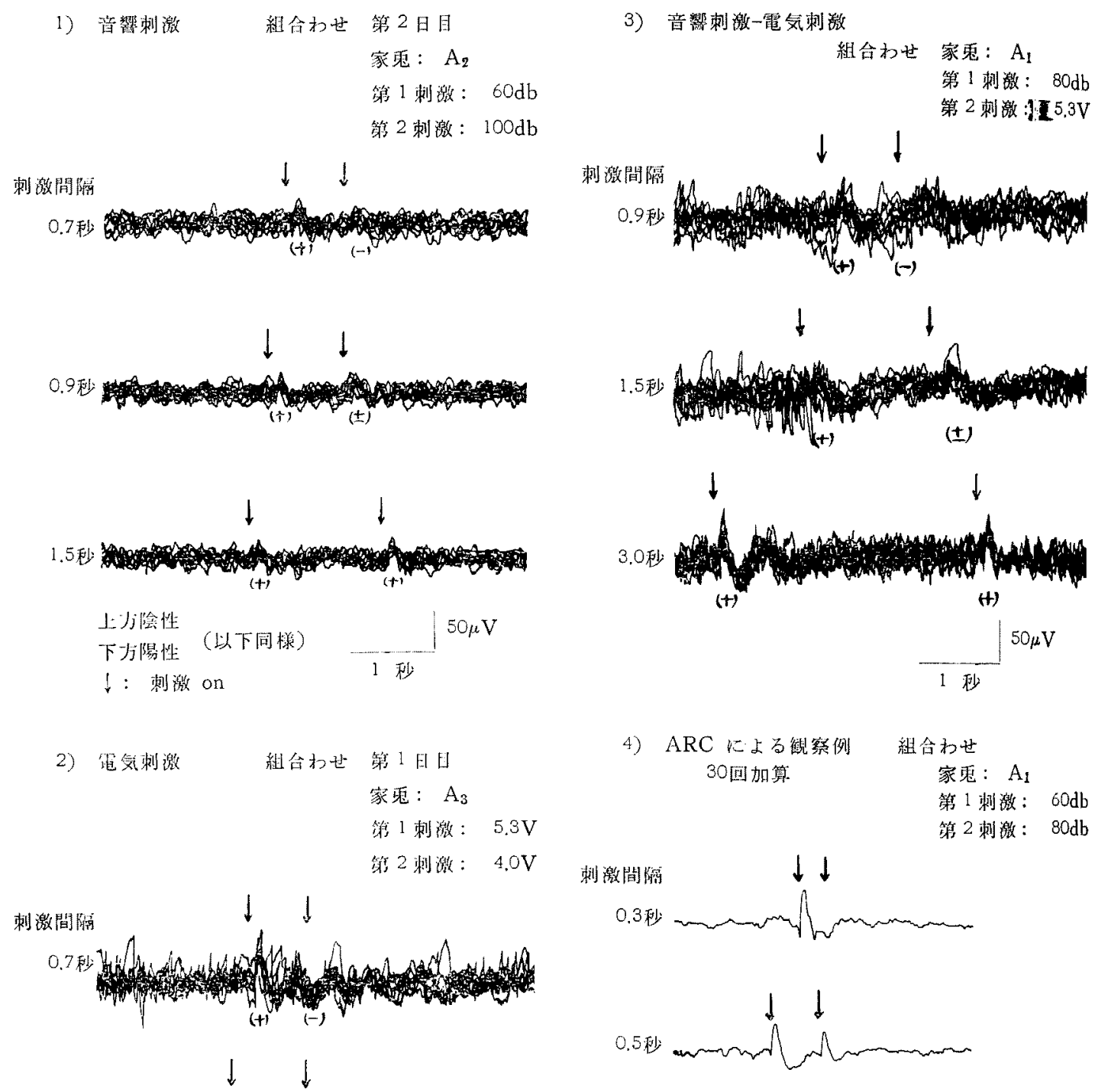

3）音篦刺激一䉓気刺潡

組合わ世 傢鬼： $A_{1}$ 第 1 刺数: $80 \mathrm{db}$

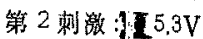
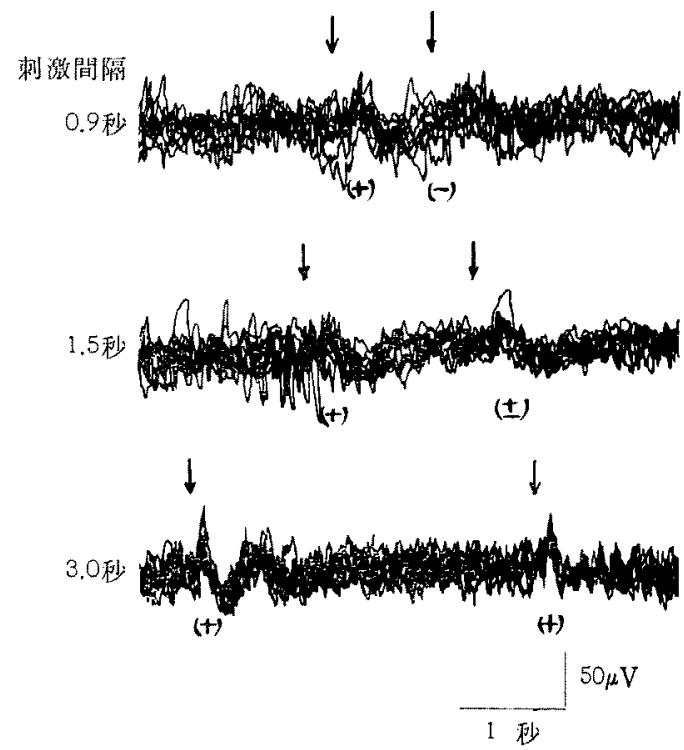

4) ARCによる峴察例組合和せ 30回加算-

家电： $A_{1}$ 第1 刺激: $60 \mathrm{db}$ 第 2 刺激： $80 \mathrm{db}$
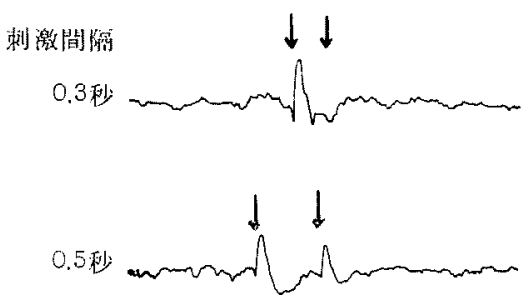

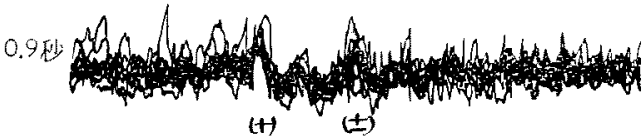
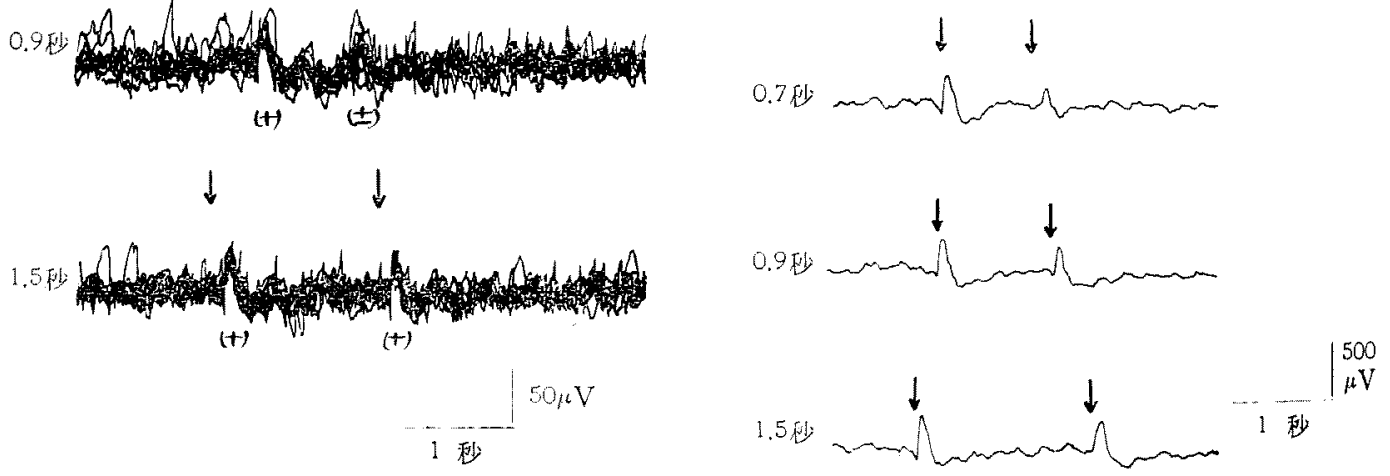
c. 第2 電気 shock のみ特性值に影整を及活し，刺 礉の強さが大になると不沈期は短くなる。

d. 因子間交互作用はあると云えない。

3) click-電気 shock 呅互作用

重ね合わせ法による不炕期は第6 表の如くである。こ の表中の值は各 3 回の実験中 2 回以上で示された值であ $\eta$ ，維計的に検討すると，click一電気 shock の場合と 㲠氛 shock-click の場合とでは，求められた刺激間噪に 有意の差が見られないことが分る。又同種刺激，同一条 件下で行つた奏駼值とも有意の差が見られないことか

第3表 重权合わせ法に上る測定絔果判定 (1)

$\mathrm{A}$ : 家鬼 B：第 1 刺激 $\mathrm{C}$ : 第 2 刺㠜

\begin{tabular}{|c|c|c|}
\hline 囷 & $F_{0}$ & 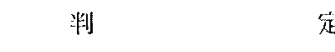 \\
\hline A & 1.47 & $F_{0 \mathrm{~A}}<\mathrm{F}_{\mathrm{dfe}}^{\mathrm{dfA}}=3.49$ \\
\hline B & 0.66 & $\mathrm{~F}_{0 \mathrm{~B}}<\mathrm{F}_{\mathrm{d} f \mathrm{c}}^{\mathrm{df}}=3.49$ \\
\hline C & 4.99 & 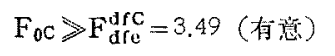 \\
\hline$A \times B$ & 1.82 & $\mathrm{~F}_{0 \mathrm{~A} \times \mathrm{B}}>\mathrm{F}_{\mathrm{dfe}}^{\mathrm{d} C \mathrm{~A} \times \mathrm{B}}=3.84$ \\
\hline $\mathrm{A} \times \mathrm{C}$ & 2.91 & $F_{0 A \times C}<F_{d f e}^{\text {df } A \times B}=3.84$ \\
\hline $\mathrm{B} \times \mathrm{C}$ & 2.72 & $F_{0 B \times C}>F_{d f e}^{d f B C}=3.84$ \\
\hline
\end{tabular}

第4表 重的合わ也法による測定結果判空 (2) A. 家鬼 B : 第 1 剩激 $\mathrm{C}$ : 第 2 刺䜤

\begin{tabular}{|c|c|c|}
\hline 因子 & $F_{0}$ & 判 \\
\hline A & 3.25 & $\mathrm{~F}_{0 \mathrm{~A}}<\mathrm{F}_{\mathrm{dfe}}^{\mathrm{dfA}}=3.49$ \\
\hline$B$ & 0.22 & $\mathrm{~F}_{\mathrm{OB}}<\mathrm{F}_{\mathrm{dfe}}^{\mathbf{d f H}}=3.49$ \\
\hline $\mathrm{C}$ & 7.06 & $F_{o c}>F_{d f e}^{d f C}=3.49$ (有崽) \\
\hline$A \times B$ & 0.40 & $F_{0 \mathrm{~A} \times \mathrm{D}}<\mathrm{F}_{\mathrm{df \textrm {f }}}^{\mathrm{dAA} \times \mathrm{B}}=3.84$ \\
\hline$A \times C$ & 1.15 & $\mathrm{~F}_{0 \mathrm{~A} \times \mathrm{C}}<\mathrm{F}_{\mathrm{df \textrm {f }}}^{\mathrm{dfA} \times \mathrm{C}}=3.84$ \\
\hline $\mathrm{B} \times \mathrm{C}$ & 2.06 & $\mathrm{~F}_{\mathrm{OB} \times \mathrm{C}}<\mathrm{F}_{\mathrm{dfe}}^{\mathrm{dfB} \times \mathrm{C}}=3.84$ \\
\hline
\end{tabular}

第 5 表 ARC に上る測起結舆判公

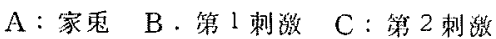

(）内は胡対不心期

\begin{tabular}{|c|c|c|}
\hline 因子 & $F_{0}\left(F^{\prime}{ }_{0}\right)$ & 判 \\
\hline $\mathrm{A}$ & $0.18(1.43)$ & $F_{0.1}\left(F_{0 A}^{\prime}\right)<F_{d f t}^{d f A}=F_{\text {dfe }}^{d f A}=3.49$ \\
\hline B & $0.13(0.89)$ & $F_{0 B}\left(F_{0 B}\right)<F_{d f o}^{d f B}=F_{d f e}^{d f B}=3.49$ \\
\hline $\mathrm{C}$ & $4.23(5.26)$ & $\begin{aligned} \mathrm{F}_{0 c}\left(\mathrm{~F}_{0 \mathrm{c}}^{\prime}\right)>\mathrm{F}_{\mathrm{dft}}^{\mathrm{dfC}}=\mathrm{F}_{\mathrm{dft}}^{\mathrm{dfC}}= & 3.49 \\
& (\text { 有意) }\end{aligned}$ \\
\hline$A \times B$ & $0.79(0.63)$ & $\begin{array}{r}F_{0 \backslash \times B}\left(F_{0 \perp \times B}\right)<F_{d f 0}^{d f A B}=F_{d f e}^{d f A \times B} \\
=3.84\end{array}$ \\
\hline$A \times C$ & $0.33(0.73)$ & $\begin{array}{r}F_{0 A \times C}\left(F^{\prime} A \times C\right)<F_{d f e}^{d f A \times C}=F_{d f e}^{\prime \prime f A \times C} \\
=3.84\end{array}$ \\
\hline $\mathrm{B} \times \mathrm{C}$ & $0.22(1.09)$ & $\begin{array}{r}F_{0 B} \times C\left(F_{0}^{\prime}{ }_{0} \times c\right)<F_{d f e}^{d f B \times C}=F_{\text {dfe }}^{\prime d f B} \\
=3.84\end{array}$ \\
\hline
\end{tabular}

第 6 表 click一電暻 shock 文正作用

\section{首位 秒}

\begin{tabular}{|c|c|c|}
\hline 家 雭 & click-霄分 shock & 電壆 shock-click \\
\hline $\mathrm{A}_{1}$ & 3.0 & 1.5 \\
\hline $\mathrm{A}_{2}$ & 0.9 & 1.5 \\
\hline $\mathrm{A}_{3}$ & 0.9 & 1.5 \\
\hline
\end{tabular}

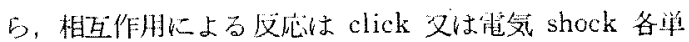
独の場含と闰し態度をとると云之よ5。

\section{考按}

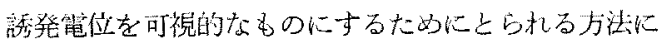

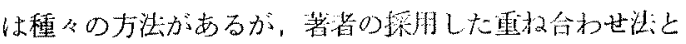

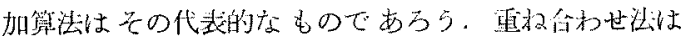

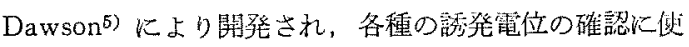
用された，これは溂激点を基篗しして幾つかの反応波形

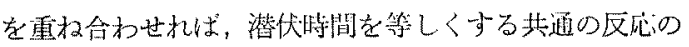
みが著明に認められるよらになる上云ら現象を応用して いる.これに詨し，加算法付搉激时点を起点として幾つ

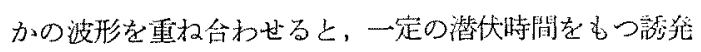

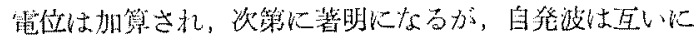
相殺されてしまらと云ら原理によるもので，Dawson ${ }^{6) 川 ~}$ が最初に発表しているが，その後 electronics の発展上 共に奏用価值を認奶られるに到つたものである。著者の 今回使朋したものは三栄测器㷱作の average 琹 computer であり，1つの硒発電位を連続的な形で捕えるこ 
とができる。

本奜験の目標として覚醒㭙大脳誘発電位については，

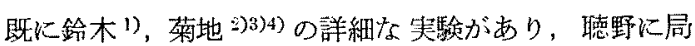
在するいわゆる primary response とは全く異なる二 次的反応であることは間違いないが，電位が比較的大き く捕え易い点が 示崚されている。

著者の目祭とした誘発䉓位殊に電気 shockによるむ のは, Forbes and Morison ${ }^{8\rangle}$ の記載した secondary discharge とは極めて密接な阙尰を有するものと思われ る. 後者は絶対不応期1/3秒，相対不応期 1 秒以上で自

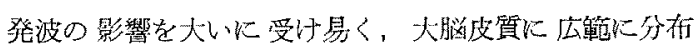
し，1側の坐骨神释の刺激に刘して両側半球で名んど同

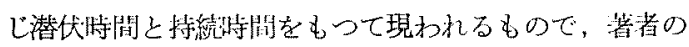
ものと桠めて似ている。しかし, secondary discharge

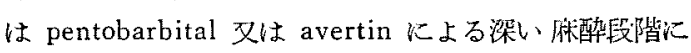
おいて現われるものであるのに対し，著者の対象は覚醒 時のるのである。

本誘発電位は人間の覚醒時と比較した場合，P. Davis 9) が最初に記载した V-potential と種々の点で共通点 を見出す。即ち 1) 種々の感覚制激 (聪覚, 視覚及灭び somatic の刺激) によつて撛発され，2）頭蓋全休に広 籁に分布するが，特に頭頂あるいはその附近で最大であ り，3）一定の潜伏時間を有するため加算, 重わ合わせ 等の操作が可能であり，4) 被検者の精神状態によつて 左右され，又反復刺激によって小さくなる傾向がある等 の V-potential の性質のあるものは本誘発電位にも認 められるものである. 但し 1) の聴賞以外の刺激によつ ても誘発されると云ら点は未だ証明されていない，本夹 験の目的とするところはこの点ではないが，㯖覚及び電 気刺激によつて語発される電位が同留的なもので互いに 干涉し合らか否が云う点にあつた。

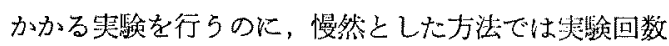
が多く手祭よく結論が得られないので，最近品質管理面

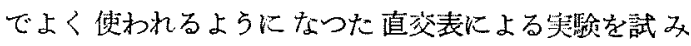
た。このう法によれば些験回数を減らすことができるだ けでなく，要因と水集の選びちによつて，各要因の主効 果と，各主要因間の交互作用を容易に知り得ることがで きるのである、殊に主観の入らない他筧的要素の強い動 物事験には適切と思われる。

さて㬰験成績を見ると，音刺激又は電気刺激各単独の 場合，いずれも第 2 刺激の及が不㐫期に影響を及ぼし， 因子間交互作用は見られないと云うことになつている。
この結論より 1) 動物の個体差がさ程大きくないと云う 点と 2) 第 1 刺激が不応期に関係しないと云う点に帐問 が起る，動物の個体差に関しては，予め被検動物を実験

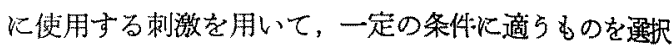
したために，有意の差を示さなかつたものと思われる。 文第1 刺激に関しては，条水準間の差が小さいことが特 性值に影響を走さなかつた 1 つ原因であると考えられ る.この点を更に確めるために ARCを使用して，第2 刺激に対する反成の出現と回復を目標として刺激間隔を 湘定したが，重ね合わせ法の場合と全く同じ成續に終る こととなつた。

不応期に関しては，家兔では菊地2》によると，第2音 刺激に上る誘発電位の発現率は刺激間隔が 2.0 秒儿なる と，1.0秒以下の特に比して極度に上笔すると云かれ，

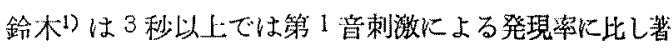
变はないと速べている。

著者の実験では使用した全刺激間瀜即ち0.1〜5.0秒に 亘り，二の間隔は絶対不応期から相対不応期の間隔を示 すものと思われるが，この变動が主として第2 籼敋の大 きさによるものであることは前記笑驗成績より明らかで ある。

secondary discharge Kついてい, Forbes and Mo. rison ${ }^{8)}$ は䟧で第 2 刺激で fullsize の放電を見るには1 秒以上の休憩を必要とするとし，Forbes et al.10) は同 しく猫で少くとも0.2 秒の刺激間隔がないと第 2 刺湤に 刘する反応が見られないとしている。

V-potential に関しては，H. Davis and Yoshie ${ }^{11)}$ は刘になつた pips を使つた実駿て，完全な回復（相詨 不応期）には約 4.5 秒を要するとし，浅輪

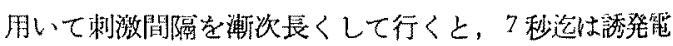

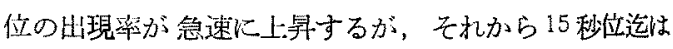
やや緩慢となり，15秒以上は刺激間隔を延ばしても余 りよくならないとしている. Perl et al.13) は click及 び純音を用いた奏䳜で，刺激間愿が10秒双はそれ以上 でしかも刺激が不规則に与えられる洔敔発反応は最もよ く現るれるとしている。

人間の V-potential の dataを直ちに家乘に此較 できないのは当然であるが，V-potential の潜伏特間 (Gastaut 14) $65 \pm 20 \mathrm{msec}$, Bancaud et al. 15) $50 \sim 100$ $\mathrm{msec}$ ) が本反応の潜代時間（鈴木1)によれば $16 \sim 25$ msec のものか゚多く，平均 $23.6 \mathrm{msec}$ ) 上り長い故その

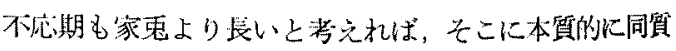
のものが，例えば求心性神経路の impulse 伝導速度と 
伝達䤄離，あるいはその間の synapse 数等から時間的 ずれを生じているのであると理解できないこともなかる 5 .

最後に音㗽刺激 (click) と䉓気刺激 (shock) を組合 わせた実験で，両刺激が同じ modality の刺激と同様に 作用することを示す data が得られた点は注目に值す る. Allison ${ }^{16)}$ は人の V-potential で click と電気 shock の cross-modality interaction を認めてはいる が, conditioning click は conditioning shock に比較 して test response を減少させる力が半分位であると L,V-potential は部分的に非特異的なるのであるに過 きないとしている，この点人間のV-potential に相当 することが予想される家兔賞醒時誘発電位に関しても， 更に検討されねばならないであるら。

\section{結語}

1) 音響刺激 (click) と電気刺激 (shock) を用い

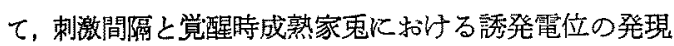
との関係を，自動重㸚合わせ装置及び ARC により直 交表を用いた夹験で観察した。

2）誘発電位は頭頂部の第頭により作製した小孔より 插入した銀線より導き，不関電極は項部に置いた。

3） 3 頭の白色成热家鬼に与えられた音響刺激は60， 80, 100dbSL $の$ click であり, 電気刺激は 4.0, 5.3, $6.6 \mathrm{~V}$ の電気 shock で，刺激間隔は $0.1 ， 0.3,0.5,0.7$, $0.9,1.5,3.0,5.0$ 秒であつた。

4) 第 2 刺激に対寸る誘発電位の発現に，動物の個体 美，第! 刺激は関係なく，第 2 制激のみ影響を及ぼし た.

5) 動物の個体差，第 1 刺激の大きさ，第 2 刺激の大 きさの間に交互作用は認められなからたた

6) 音製刺激，電気刺激の交互作用を見ると，音響刺 激又は電気刺激が各単独の場合と同し態度をとるので， 本誘発電位は動物の睡眠時に和ける secondary discharge あるいは人間の V-potential に相当する非特異性 誘発電位と考㿝られ。

\section{文 献}

1)鈴木裕：音繁刺戟により，覚醮時家鬼に見られた

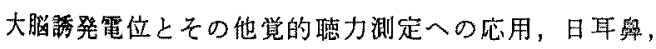
$63: 24,1960$ ，2）㐘地俊次：音響刺激に上る家乘大 媨諉発電位の钼察，第1報 音留刺激間隔上誘発電位上

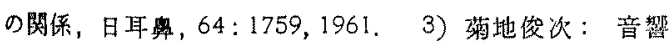
刺による家电大脳誘発電位の钼察，第 2 報 1 音の存

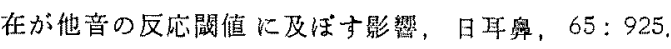

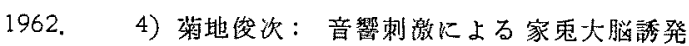
電位の钼察，第3 報 幼若家児の誘発電位，日耳鬼， $66: 273,1963.5)$ Dawson, G.D.: Cerebral res. ponses to electrical stimulation of peripheral nerve in man, J. Neurol. Psychiat., 10: 134, 1947.

Dawson, G.D.: A summation technique for detecting small signals in a large irregular background, J. Physiol., 115:2, 1951. $\quad$ 7) Dawson, G.D.: A summation technique for the detection of small evoked potentials, EEG Clin. Neurophysiol., 6:65, 1954. 8) Forbes, A. and Morison, B.R.: Cortical response to sensory stimulation under deep barbiturate narcosis, J. Neurophysiol, 2 : 112, 1939. 9) Davis, P.A. Effects of acoustic stimuli on the waking human brain, J. Neurophysiol., 2: 494, 1939. 10) Forbes, A., Battista, A.F., Chatfield, P.O. and Garcia, J.P.: Refractory phase in cerebral mechanisms, EEG Clin. Neurophysiol, 1: 141, 1949. 11) H. Davis and Yoshie, N.: Some relation of the cortical-evoked response to the intensity of the acoustic stimulus, The 66th meeting of

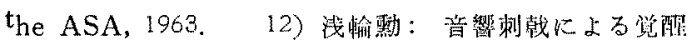
時人間大脳の誘発電位之乙の他覚的娭查法への店用，日 耳舆，62:743, 1959. 13) Perl, E., Galamboss, R. and Glorig, A.: The estimation of hearing threshold by electroenceplalograply, EEG Clin. Neurophysiol., 5: 501, 1953. 14) Gastaut, Y.: Les pointes négatives évoquées sur le vertex, leur sig. nification psychophysiologique et pathologique, Rev. Neurol., 89: 382, 1953, 15) Bancaud, J., Bloch, V. et Billard, J.: Contribution EEG a l':ude des potentiels évoqués chez l'homme au niveau du vertex, Rev. Neurol. $89 \vdots 399,1953$, 16) Allison, T.: Recovery functions of somatosensory evoked responses in man, EEG Clin. Neurophysiol., $14: 331,1962$.

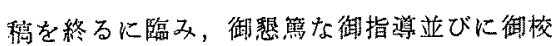
閲を賜わつた恩師鈴木䈍郎教授に梁く謝意を表 します

（原船到着 $=$ 昭和 39.6 .3 日） 